\title{
Potensi Tepung Pisang Uter (Musa Acuminata) Sebagai Pangan Fungsional Untuk Menurunkan Kolesterol
}

\author{
POTENTIAL OF UTER BANANA FLOUR \\ (Musa acuminata) AS A FUNCTIONAL FOOD TO REDUCE CHOLESTEROL
}

\author{
Hastin Dyah Kusumawardani ${ }^{1}$, Yustinus Marsono ${ }^{2}$, Agnes Murdiati ${ }^{2}$, dan Mohamad Samsudin ${ }^{1}$ \\ ${ }^{1}$ Balai Penelitian dan Pengembangan Kesehatan Magelang Indonesia \\ ${ }^{2}$ Fakultas Teknologi Pertanian UGM Indonesia \\ *Email : khiaraqila011@gmail.com
}

Submitted: 13-05-2019, Revised : 25-07-2019, Revised : 18-09-2019, Accepted : 25-11-2019

\begin{abstract}
Cholesterol is needed in certain concentration as to avoid health effects. Efforts to handle hypercholesterolemia can be done by utilizing the content of resistant starch in Uter bananas flour. The aim of this study was to prove the hypocholesterolemic effect of Uter Banana flour in hypercholesterolemic Spraque-Dawlwy rats. Therefore, experimental research using animals to determine the hypocholesterolemic effect of Uter banana flour was carried out for 28 days, in Spraque Dawlwy male rats aged 2 months, weighing \pm 200 grams. Rats were divided into 5 treatment groups. Group I was normal rats group, group II was hypercholesterol rats without treatment, group III was hypercholesterol rats with pulp fruit flour diet, group IV was hypercholesterol rats with whole fruit flour diet, group $V$ was hypercholesterol rats with peel fruit flour diet. Each diet contained $100 \mathrm{mg} / \mathrm{kgBB}$. Statistical analysis showed that a diet of pulp fruit flour and whole fruit flour can reduce levels of total cholesterol, triglycerides, and LDL significantly $(p<0.05)$. Digesta characteristics differed among the treatment group and the hypercholesterolemia group without treatment $(p<0.05)$. The whole fruit flour has ability to lower cholesterol better than pulp fruit flour, whereas, peel fruit flour has no hypocholesterolemic effects.
\end{abstract}

Keywords: hypercholesterolemia, resistant starch, Uter Banana Flou

\begin{abstract}
Abstrak
Kolesterol dibutuhkan oleh tubuh dalam jumlah tertentu agar tidak membahayakan kesehatan. Upaya penanganan hiperkolesterolemia dapat dilakukan dengan memanfaatkan kandungan pati resisten dalam pisang Uter. Tujuan dari penelitian ini adalah membuktikan efek hipokolesterolemik tepung Pisang Uter pada tikus Sprague Dawley hiperkolesterol. Untuk itu penelitian eksperimen dengan hewan coba untuk mengetahui efek hipokolesterolemik tepung pisang Uter dilakukan selama 28 hari, pada tikus Spraque Dawlwy jantan umur 2 bulan, dengan berat \pm 200 gram. Tikus dibagi menjadi 5 kelompok perlakuan. Kelompok I adalah kelompok tikus normal, kelompok II adalah tikus hiperkolesterol tanpa perlakuan, kelompok III tikus hiperkolesterol dengan diet tepung daging buah, kelompok IV adalah tikus hiperkolesterol dengan diet tepung buah utuh, kelompok $\mathrm{V}$ adalah tikus hiperkolesterol dengan diet tepung kulit buah, masing-masing diberikan diet $100 \mathrm{mg} / \mathrm{kgBB}$. Hasil uji statistik menunjukkan bahwa diet tepung daging buah dan tepung buah utuh dapat menurunkan kadar kolesterol total, trigliserida, dan LDL secara nyata $(p<0,05)$. Karakteristik digesta berbeda antara perlakuan dan kelompok tikus hiperkolesterol tanpa perlakuan $(\mathrm{p}<0,05)$. Tepung buah utuh mempunyai kemampuan menurunkan kolesterol lebih baik dibandingkan tepung daging buah. Tepung kulit buah tidak mempunyai efek hipokolesterolemik.
\end{abstract}

Kata kunci: Hiperkolesterol, pati resisten, tepung Pisang Uter 


\section{PENDAHULUAN}

Kemajuan teknologi dewasa ini mempengaruhi gaya hidup masyarakat, salah satunya adalah pola makan. Perubahan pola makan menjadi tinggi gula, lemak, dan garam yang akhirnya berujung pada meningkatnya kejadian penyakit tidak menular (PTM). Riskesdas tahun 2018 melaporkan proporsi penduduk yang biasa mengonsumsi makanan berlemak lebih dari satu kali perhari mencapai $41,78 \%$, lebih banyak pada penduduk wanita, yaitu $42,8 \%$ dan tinggal di perkotaan $43,68 \%{ }^{1}$ Konsumsi makanan tinggi lemak secara terus menerus dapat memicu hiperlipidemia atau hiperkolesterolemia yang menjadi faktor risiko penyakit jantung koroner.

Kolesterol merupakan substansi lemak hasil metabolisme yang banyak ditemukan dalam struktur tubuh manusia maupun hewan. Kolesterol dalam tubuh sangat esensial untuk kebutuhan sel dan juga merupakan bahan baku sintesis empedu. Meskipun keberadaannya sangat dibutuhkan, akan tetapi apabila jumlahnya berlebih dalam tubuh, akan berdampak tidak baik bagi tubuh. Berbagai upaya menurunkan kadar kolesterol dalam darah dapat dilakukan dengan pemberian obat kimiawi maupun obat tradisional atau dengan pemberian pangan fungsional, yaitu pangan konvensional yang mengandung komponen bioaktif tertentu yang dapat menurunkan resiko penyakit degeneratif. ${ }^{2}$ Sebuah penelitian tentang konsumsi crackers kentang hitam, terbukti dapat menurunkan kadar kolesterol, trigliserida, dan LDL pada hewan coba hiperkolesterol. Efek hipokolesterolemik ini disebabkan kandungan pati resisten pada tepung kentang hitam sebagai bahan baku pembuatan crackers. ${ }^{3}$ Pati resisten merupakan pati yang tidak dapat dicerna oleh enzim pencernaan dan tahan terhadap asam lambung sehingga dapat mencapai usus besar untuk difermentasi oleh bakteri probiotik. $^{4}$

Beberapa efek fisiologis potensial dari pati resisten adalah menjaga kesehatan usus besar, sebagai prebiotik yang membantu menjaga kesehatan kolon, mengontrol glikemik dan respon insulin, memberi rasa kenyang dan menurunkan intake energi, serta memperbaiki profil lipid darah. ${ }^{5}$ Penelitian pada tikus menunjukkan bahwa pemberian pati resisten berdampak pada penurunan kolesterol yang signifikan. Sebuah penelitian melaporkan efek hipokolesterolemik pati resisten dalam kacang merah pada tikus dislipidemi. Pemberian serat pangan sebanyak $14,38 \%$ dari total pakan efektif memperbaiki parameter lipida darah melalui pembuangan kolesterol pada feses. ${ }^{6}$ Penelitian lain melaporkan efek hipokolesterolemik dan hipoglikemik tepung pra-masak pisang tanduk dan Raja Nangka yang diberikan pada hewan coba. Hal ini disebabkan karena kandungan serat pangan pada kedua tepung tersebut. Efek lain dari pemberian diet tepung pisang adalah peningkatan konsentrasi Short Chain Fatty Acid (SCFA) yang berpengaruh pada kesehatan kolon. ${ }^{7}$

Pisang merupakan sumber karbohidrat, vitamin dan mineral. Komponen karbohidrat terbesar pada buah pisang adalah pati pada daging buahnya, dan sebanyak 15-208\% akan diubah menjadi sukrosa, glukosa dan fruktosa pada saat pisang matang. ${ }^{8}$ Pisang Uter merupakan salah satu pisang dari golongan Plantain yang pemanfaatannya masih terbatas untuk pakan burung dan bahan baku pembuatan keripik pisang. Kandungan pati resisten tepung buah utuh, daging buah dan kulit buah pisang Uter berturut-turut $14,398 \%, 17,588 \%$ dan 11 persen berat kering. Tepung pisang Uter mengandung serat pangan berturut-turut $8,218 \%, 7,478 \%$ dan $31,128 \%$ berat kering. ${ }^{9}$

Tujuan penelitian ini adalah untuk membuktikan potensi tepung pisang Uter dalam menurunkan kadar kolesterol darah. Diharapkan penelitian ini dapat memberikan manfaat bagi masyarakat sebagai salah satu alternatif pangan fungsional untuk menurunkan kadar kolesterol.

\section{BAHAN DAN METODE}

Penelitian ini merupakan penelitian eksperimen. Bahan baku yang digunakan adalah tepung buah utuh, tepung daging buah, dan tepung kulit buah pisang Uter (Musa acuminata) yang diambil dari petani di desa Patran, Madurejo, Prambanan, Sleman. Tepung pisang dibuat dengan cara mengambil pisang mengkal, mengukus untuk menghilangkan getah, mengupas, memotong tipis-tipis, mengeringkan dalam cabinet dryer selama 24 jam pada suhu 
$50^{\circ} \mathrm{C}$, dan menggiling serta diayak 60 mesh. Untuk pengujian in vivo menggunakan tikus Rattus novergicus galur Spraque-Dawlwy (SD) yang diperoleh dari UPHP Universitas Gadjah Mada dengan kriteria:

a. Kriteria inklusi: tikus jenis Rattus novergicus galur Spraque-Dawlwy (SD), jenis kelamin jantan, umur 2 bulan, berat badan \pm 200 gram, tikus aktif.

b. Kriteria eksklusi: tikus tidak sehat dan tidak mau makan, tikus mengalami penurunan aktivitas fisik.

Tikus dibagi menjadi lima (5) kelompok yaitu : (1) STD (kelompok tikus sehat diberikan diet pakan standar AIN-93M); (2) HK-KN (kelompok tikus hiperkolesterol diberikan diet pakan standar AIN-93M); (3) HK-DB (kelompok tikus hiperkolesterol diberikan diet tepung daging buah pisang Uter); (4) HK-BU (kelompok tikus hiperkolesterol diberikan diet tepung buah utuh pisang Uter); (5) HK-KB (kelompok tikus hiperkolesterol diberikan diet tepung kulit buah).

Jumlah sampel penelitian adalah 30 ekor tikus yang didapatkan dari perhitungan rumus Federer $(\mathrm{t}-1)(\mathrm{n}-1) \geq 15$

$\mathrm{t}=$ kelompok perlakuan $(5$ kelompok)

$\mathrm{n}=$ jumlah sampel tiap kelompok yang akan dicari. ${ }^{10}$

Komposisi pakan mengacu pada AIN (American Institute of Nutrition) 93M. ${ }^{11}$ (pustaka ini yang terakhir menjelaskan tentang komposisi AIN 93M) Komposisi pangan tikus dapat dilihat di Tabel 1. Penelitian dilakukan di Laboratorium Pusat Studi Pangan dan Gizi UGM serta Laboratorium Biokimia Balai Litbangkes Magelang.

Variabel terikat dalam penelitian eksperimental merupakan respon hewan coba terhadap perlakuan yang diberikan. Dalam penelitian ini variabel terikat adalah profil lipid (kadar kolesterol total, LDL, HDL dan trigliserida) darah dan profil digesta (kolesterol digesta, kadar air, berat digesta, SCFA dan $\mathrm{pH}$ ). Pengambilan darah dilakukan melalui sinus orbitalis sebanyak $1 \mathrm{ml}$ dengan menggunakan mikrohaematocrit dan dimasukkan dalam tabung appendorf.

Variabel bebas dalam penelitian ini adalah diet tepung buah utuh, tepung daging buah, dan tepung kulit buah pisang Uter.

Klirens Etik Penelitian ini dimintakan dari LPPT Universitas Gadjah Mada, dan mendapatkan keterangan Kelaikan Etik No. 244/ KEC-LPPT/IV/2015.

\section{Pemberian Perlakuan}

Setiapkelompok hewan cobadipersiapkan dalam kandang yang terpisah. Sebelum perlakuan tikus ditimbang dan diamati kesehatan fisiknya. Selain pemberian diet standar AIN 93M, pada empat kelompok tikus perlakuan juga diberikan induksi lemak sapi yang diberikan per oral sebagai makanan untuk menginduksi kenaikan kadar kolesterol. Cara pembuatannya yaitu dengan memanaskan lemak sapi hingga diperoleh minyak lemak sapi, kemudian diinduksikan pada 24 ekor tikus (4 kelompok perlakuan) melalui sonde sebelum tikus diberikan pakan standar sebanyak $2 \mathrm{ml}$ selama 7 hari. Parameter terjadinya hiperkolesterol adalah kadar total kolesterol mencapai >130 mg/dL, kadar normal kolesterol pada tikus galur Spraque-Dawlwy adalah 40-130 $\mathrm{mg} / \mathrm{dL} .{ }^{12}$ Pakan standar dan pakan modifikasi tepung pisang serta air minum diberikan secara ad libitum. Pada akhir intervensi tikus dibedah untuk diambil sekumnya dan dianalisis profil digesta yang meliputi kadar air, berat sekum, $\mathrm{pH}$, kolesterol dan Short Chain Fatty Acid (SCFA). Profil lipid tikus dianalisis sebanyak empat kali pada hari ke 2, 14, 28 dan 42.

\section{Metode Analisis}

Analisa spesimen digesta (isi usus) untuk kolesterol digesta metode LiebermanBuchard. ${ }^{13}$ SCFA digesta dianalisis dengan metode kromatografi. ${ }^{14}$ Berat digesta diketahui dengan menimbang menggunakan timbangan analitik, $\mathrm{pH}$ digesta diukur dengan $\mathrm{pH}$ meter. Trigliserida diukur dengan metode GPO-PAP, kolesterol total diukur dengan metode CHODPAP, kolesterol HDL diukur dengan perlakuan presipitasi, sedangkan kolesterol LDL ditentukan dengan rumus:

Kolesterol LDL $(\mathrm{mg} / \mathrm{dL})=$ kolesterol totalkolesterol HDL-trigliserida/5. ${ }^{15}$ 
Analisis data dilakukan dengan menggunakan uji statistik One Way Anova setelah sebelumnya diuji normalitas dan homogenitasnya. Apabila hasil uji anova menunjukkan ada perbedaan, dilanjutkan dengan uji Post Hoc Tukey.

\section{HASIL \\ Profil Lipid \\ Kolesterol Total}

Terjadi peningkatan kadar kolesterol total setelah induksi selama 7 hari, yang menunjukkan semua tikus perlakuan sudah mengalami hiperkolesterolemia ( $>130 \mathrm{mg} / \mathrm{dL})$. Pada hari ke 28 (2 minggu intervensi) terjadi penurunan pada kelompok tikus hiperkolesterolemia dengan diet tepung buah utuh dan daging buah. Penurunan pada kelompok ini terjadi hingga akhir intervensi. Perubahan kadar kolesterol total kelompok tikus dapat dilihat pada Gambar 1.

\section{Tabel 1. Komposisi Pakan}

\begin{tabular}{|c|c|c|c|c|}
\hline & Standar* & HK-DB & HK-BU & HK-KB \\
\hline Komponen & $\begin{array}{c}\text { Jumlah } \\
\text { (g) }\end{array}$ & $\begin{array}{c}\text { Jumlah } \\
\text { (g) }\end{array}$ & $\begin{array}{c}\text { Jumlah } \\
\text { (g) }\end{array}$ & $\begin{array}{c}\text { Jumlah } \\
\text { (g) }\end{array}$ \\
\hline Pati jagung & 620,7 & - & - & - \\
\hline Tp daging buah & - & 828,81 & - & - \\
\hline Tp buah utuh & - & - & 850,43 & - \\
\hline Tp kulit & - & - & - & 1167,53 \\
\hline Sukrosa & 100 & - & - & - \\
\hline Kasein & 140 & 88,45 & 87,95 & 52,91 \\
\hline Minyak kedelai & 40 & 36,02 & 28,94 & - \\
\hline Mineral mix & 35 & 22,76 & 7,79 & - \\
\hline Selulosa & 50 & - & - & - \\
\hline Vitamin mix & 10 & 10 & 10 & 10 \\
\hline L_cystein & 1,8 & 1,8 & 1,8 & 1,8 \\
\hline Cholin bitartrat & 2,5 & 2,5 & 2,5 & 2,5 \\
\hline
\end{tabular}

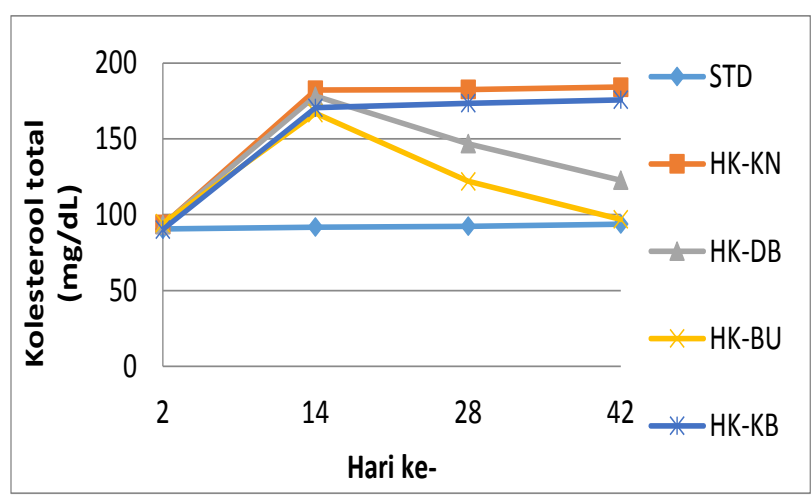

Gambar 1. Perubahan Kadar Kolesterol Total

\section{Kolesterol LDL}

Peningkatan kadar kolesterol total dan LDL darah dapat disebabkan oleh peningkatan konsumsi lemak jenuh dan kolesterol tinggi. Rasio kolesterol total terhadap HDL juga meningkat, sebaliknya kadar HDL akan menurun. Asupan lemak tak jenuh yang lebih tinggi akan menurunkan kadar LDL dan meningkatkan kadar HDL. ${ }^{15}$ Perubahan kadar kolesterol LDL selama penelitian dapat dilihat pada Gambar 2.

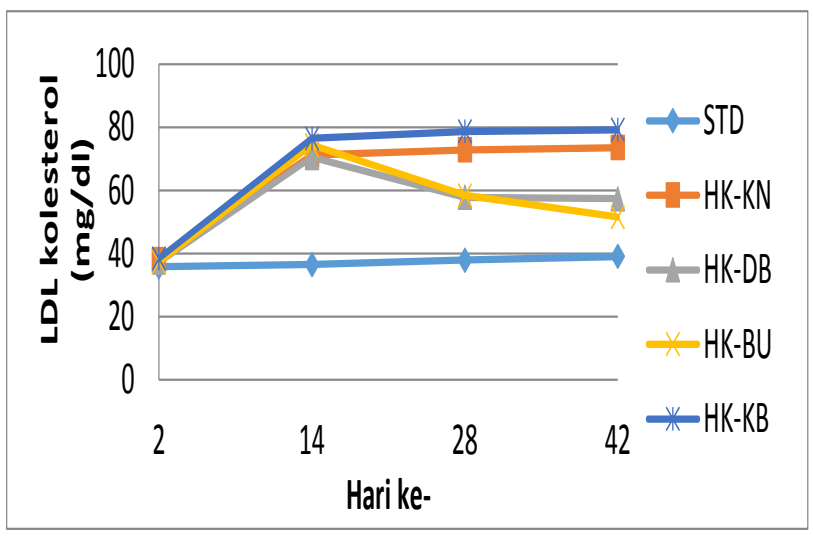

Gambar 2. Perubahan Kadar Kolesterol LDL

\section{Kolesterol HDL}

Kolesterol HDL sering disebut dengan kolesterol baik karena merupakan lipoprotein yang mengangkut lipid dari perifer menuju ke hepar. Gambar 3 menunjukkan perubahan kadar HDL darah. Terjadi peningkatan kadar kolesterol HDL yang berbeda nyata. Peningkatan kadar HDL dengan pemberian diet tepung buah utuh sebesar 59,85\% dan 56,26\% pada kelompok diet tepung daging buah.

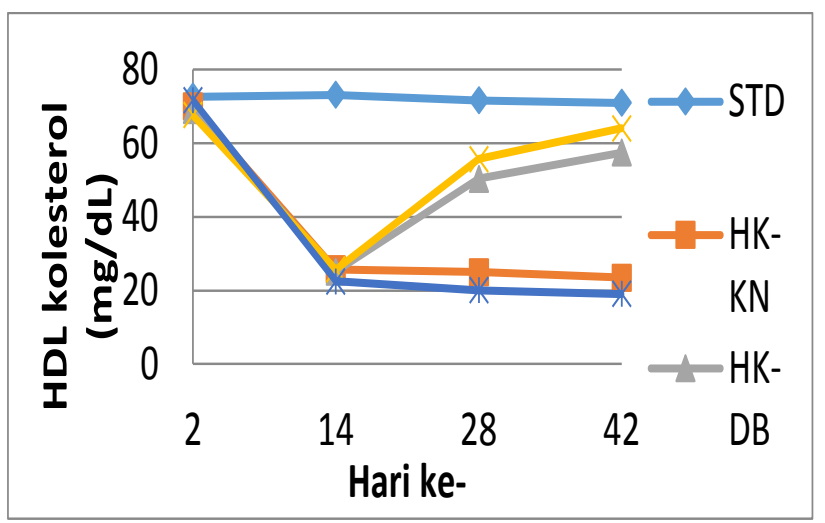

Gambar 3. Perubahan Kadar Kolesterol HDL 


\section{Trigliserida}

Peningkatan kadar trigliserida di pengaruhi oleh faktor genetik dan konsumsi karbohidrat, lemak dan juga alkohol, selain itu juga dipengaruhi oleh aktivitas enzim LPL (lipoprotein lipase). ${ }^{12}$ Gambar 4 menunjukkan perubahan kadar trigliserida dalam darah tikus. Terjadi penurunan kadar trigliserida yang bermakna setelah pemberian diet tepung buah utuh sebanyak $40,22 \%$ dan $30,5 \%$ pada diet tepung daging buah.

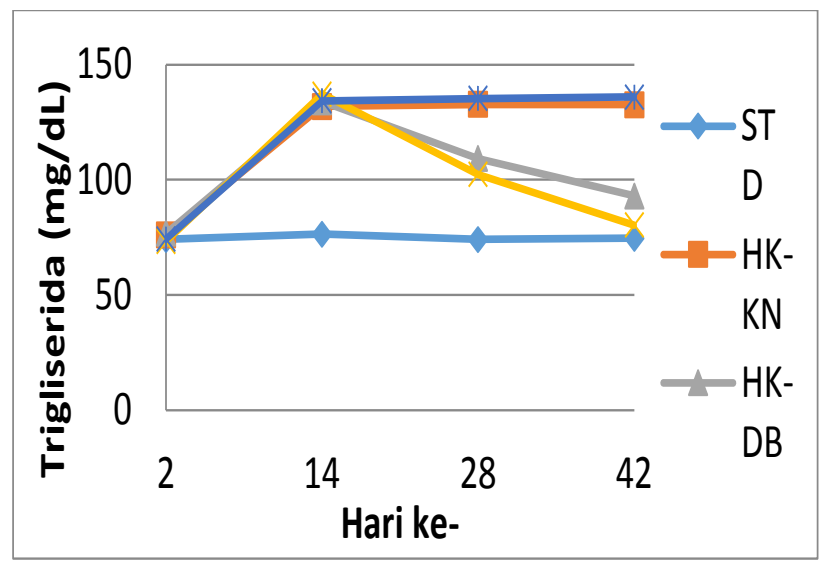

Gambar 4. Perubahan Kadar Trigliserida

\section{Profil Digesta}

Berat Total dan Kadar Air Digesta

Berat total digesta pada kelompok tikus hiperkolesterol dengan diet tepung buah utuh dan tepung daging buah lebih berat dibandingkan kelompok lain. Berat total digesta berbanding lurus dengan kadar air digesta. Perbedaan berat total dan kadar air kelompok ini berbeda bermakna $(p<0,05)$ dibandingkan kelompok yang lain. Berat total dan kadar air digesta tikus pada akhir intervensi dapat dilihat pada Tabel 2.

Tabel 2. Berat Digesta, Kadar Air dan Volume Cairan

\begin{tabular}{cccc}
\hline Perlakuan & $\begin{array}{c}\text { Berat } \\
\text { digesta (g) }\end{array}$ & $\begin{array}{c}\text { Kadar air } \\
\text { digesta }(\%)\end{array}$ & $\begin{array}{c}\text { Volume } \\
\text { Cairan }(\mathbf{m l})\end{array}$ \\
\hline STD & $2,9 \pm 0,81^{\mathrm{b}}$ & $62,74 \pm 5,59^{\mathrm{b}}$ & $1,82 \pm 0,19^{\mathrm{b}}$ \\
$\mathrm{HK}-\mathrm{KN}$ & $2,12 \pm 0,77^{\mathrm{a}}$ & $42,10 \pm 6,05^{\mathrm{a}}$ & $0,89 \pm 0,12^{\mathrm{a}}$ \\
$\mathrm{HK}-\mathrm{DB}$ & $4,09 \pm 0,14^{\mathrm{c}}$ & $81,53 \pm 7,21^{\mathrm{c}}$ & $3,34 \pm 0,37^{\mathrm{c}}$ \\
$\mathrm{HK}-\mathrm{BU}$ & $4,13 \pm 0,15^{\mathrm{c}}$ & $85,16 \pm 0,79^{\mathrm{c}}$ & $3,52 \pm 0,13^{\mathrm{c}}$ \\
HK-KB & $2,14 \pm 0,42^{\mathrm{a}}$ & $46,09 \pm 1,75^{\mathrm{a}}$ & $0,99 \pm 0,02^{\mathrm{a}}$ \\
\hline
\end{tabular}

Keterangan: notasi yang berbeda dalam satu kolom menunjukkan beda nyata $(\mathrm{p}<0,05)$.

Volume Cairan: hasil perhitungan antara kadar air digesta dan berat digesta
Berat digesta tertinggi pada kelompok tikus HK-BU yaitu 4,13 gram diikuti kelompok tikus HK-DB 4,01 gram. Berat digesta tikus STD rata-rata 2,9 gram sedangkan kelompok tikus HK-KN 2,1 gram, dan pada kelompok tikus HK-KB rata-rata 2,14 gram. Kadar air tertinggi pada kelompok tikus HK-BU, mencapai 85,16\% diikuti kelompok tikus HK-DB sebanyak 81,53\%, kelompok tikus STD 62,74\% dan kelompok tikus HK-KN 42,1\% sedangkan pada kelompok tikus HK-KB kadar air digesta 46,09\%.

\section{Kolesterol Digesta}

Kolesterol digesta pada kelompok tikus hiperkolesterol dengan diet tepung buah utuh lebih tinggi dibandingkan kelompok tikus hiperkolesterol yang lain. Kolesterol digesta terendah pada kelompok tikus hiperkolesterol tanpa perlakuan. Kolesterol digesta tikus setelah akhir intervensi selengkapnya dapat dilihat pada Gambar 5.

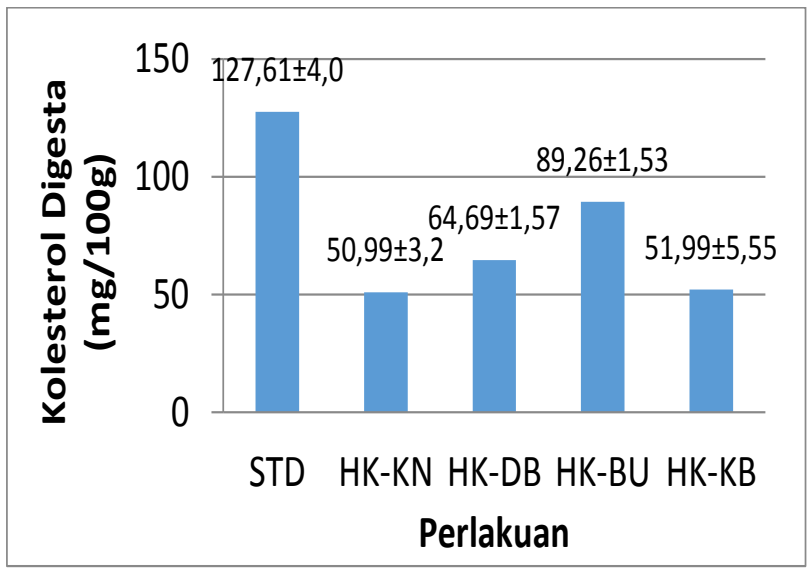

Gambar 5. Kolesterol Digesta Tikus

\section{Konsentrasi Asam Lemak Rantai Pendek dan pH Digesta}

Konsentrasi asam lemak rantai pendek pada semua kelompok tikus tertinggi asetat diikuti propionat dan butirat. Pool asam lemak rantai pendek terbanyak pada kelompok tikus hiperkolesterol dengan diet tepung buah utuh berbeda nyata dengan kelompok yang lain. $\mathrm{PH}$ terendah terlihat pada kelompok hiperkolesterol tanpa perlakuan. Konsentrasi asam lemak rantai pendek dan $\mathrm{pH}$ digesta tikus dapat dilihat pada Tabel 3. 
Tabel 3. Asam Lemak Rantai Pendek dan pH

\begin{tabular}{ccccccc}
\hline \multirow{2}{*}{ Perlakuan } & \multicolumn{7}{c}{ Konsentrasi SCFA (mmol/l) } & & PH \\
\cline { 2 - 6 } & Asetat & Propionat & Butirat & Total & Pool (mmol) & pH \\
\cline { 2 - 6 } STD & $88,06 \pm 34,9^{\mathrm{b}}$ & $36,92 \pm 11,96^{\mathrm{b}}$ & $12,49 \pm 4,31^{\mathrm{b}}$ & $137,47 \pm 50,91^{\mathrm{b}}$ & $0,25 \pm 0,10^{\mathrm{b}}$ & $6,7 \pm 0,03^{\mathrm{c}}$ \\
HK-KN & $35,79 \pm 8,72^{\mathrm{a}}$ & $13,51 \pm 3,34^{\mathrm{a}}$ & $5,01 \pm 1,17^{\mathrm{a}}$ & $54,32 \pm 13,06^{\mathrm{a}}$ & $0,03 \pm 0,01^{\mathrm{a}}$ & $6,5 \pm 0,07^{\mathrm{a}}$ \\
HK-DB & $25,53 \pm 9,78^{\mathrm{a}}$ & $10,68 \pm 4,25^{\mathrm{a}}$ & $4,24 \pm 1,96^{\mathrm{a}}$ & $40,46 \pm 15,73^{\mathrm{a}}$ & $0,18 \pm 0,06^{\mathrm{b}}$ & $6,7 \pm 0,05^{\mathrm{c}}$ \\
HK-BU & $88,37 \pm 16,59^{\mathrm{b}}$ & $37,45 \pm 4,96^{\mathrm{b}}$ & $12,48 \pm 2,49^{\mathrm{b}}$ & $138,31 \pm 23,07^{\mathrm{b}}$ & $0,49 \pm 0,07^{\mathrm{c}}$ & $6,7 \pm 0,04^{\mathrm{c}}$ \\
HK-KB & $25,56 \pm 3,02^{\mathrm{a}}$ & $10,86 \pm 1,09^{\mathrm{a}}$ & $4,37 \pm 0,45^{\mathrm{a}}$ & $40,79 \pm 4,57^{\mathrm{a}}$ & $0,04 \pm 0,00^{\mathrm{a}}$ & $6,6 \pm 0,04^{\mathrm{b}}$ \\
\hline
\end{tabular}

Keterangan : notasi yang berbeda dalam satu kolom menunjukkan beda nyata $(\mathrm{p}<0,05)$

\section{PEMBAHASAN Profil Lipid}

Penurunan kolesterol total paling banyak terjadi pada kelompok tikus hiperkolesterol dengan diet tepung buah utuh, pada akhir intervensi menjadi sama dengan kelompok tikus normal. Pada kelompok tikus hiperkolesterol dengan diet tepung daging buah mengalami penurunan selama intervensi, akan tetapi tidak sebanyak kelompok tikus diet tepung buah utuh. Penurunan kolesterol ini disebabkan adanya pati resisten yang menghalangi absorpsi kolesterol dalam usus halus. ${ }^{15}$ Selain itu, pati resisten mempunyai kemampuan mengikat asam empedu yang kemudian akan terbuang bersama dengan feses. Asam empedu mengemulsikan lemak hingga terurai menjadi asam lemak yang akan diserap tubuh. Agar metabolisme lemak tidak terganggu, maka harus tersedia asam empedu di dalam sistem pencernaan. Pada akhirnya kolesterol dalam darah akan diubah menjadi asam empedu sehingga kolesterol dalam darah menurun.

Sifat serat yang tidak tercerna dalam saluran pencernaan atas, memiliki viskositas yang tinggi, merupakan polimer alami dan mempunyai kemampuan pengikatan air yang tinggi dan dilaporkan dapat mengikat kolesterol dalam pencernaan sehingga menurunkan kolesterol dalam darah. ${ }^{16}$

Hasil penelitian ini sejalan dengan penelitian lain yang menjelaskan tentang efek hipokolesterolemik tepung pisang tanduk dan raja nangka. Penelitian ini menyatakan bahwa pati resisten mampu mengikat kolesterol dalam usus. Pati resisten mempunyai kemampuan menghasilkan digesta yang viskositasnya tinggi, yang berefek pada lambatnya absorpsi kolesterol.
Dengan demikian akan terjadi akumulasi kolesterol terutama di sekum. Semakin banyak kolesterol yang diikat maka akan semakin banyak pula kolesterol yang ada dalam digesta. Tingginya kadar kolesterol digesta ini juga menunjukkan rendahnya penyerapan kolesterol di usus karena cepatnya laju ekskresi digesta. ${ }^{7}$

\section{Profil Digesta}

Kadar kolesterol digesta tertinggi pada kelompok tikus perlakuan, kelompok HK-BU mempunyai kadar kolesterol digesta tertinggi dan terendah pada kelompok tikus HK-KN $(50,99$ $\mathrm{mg} / 100 \mathrm{~g}$ ). Hasil analisis statistik menunjukkan pemberian diet tepung daging buah dan buah utuh pisang Uter dapat meningkatkan kadar kolesterol digesta tikus secara nyata $(p<0,05)$. Hal yang sama dilaporkan oleh peneliti lain yang menunjukkan peningkatan kadar kolesterol digesta pada tikus hiperkolesterol yang diberi buah jambu biji merah. Peningkatan kolesterol dalam digesta tikus disebabkan kandungan serat yang mampu meningkatkan ekskresi kolesterol. ${ }^{13}$ Mekanisme penurunan kolesterol karena adanya kandungan pati resisten pada kedua tepung, dimana pati resisten mempunyai viskositas yang tinggi dan mampu mengikat kolesterol dalam pencernaan, sehingga mampu menurunkan kadar kolesterol dalam darah. Hal ini dibuktikan dengan adanya kadar kolesterol dalam digesta yang berbeda bermakna antara tikus yang diet tepung pisang uter dengan tikus hiperkolesterol dengan diet tanpa tepung pisang uter.

Penurunan kolesterol darah dapat juga disebabkan adanya hasil fermentasi serat pangan termasuk pati resisten. Fermentasi serat dalam sekum menghasilkan produk berupa gas seperti gas hidrogen, metana, karbondioksida dan asam lemak rantai pendek (SCFA) seperti 
asetat, propionat dan butirat. Berdasarkan hasil analisis, konsentrasi asam lemak rantai pendek berbeda nyata pada kelompok tikus dengan diet buah utuh dengan kelompok tikus dengan diet tepung daging buah, tepung kulit dan kelompok tikus hiperkolesterol dengan diet pakan standar tetapi tidak berbeda nyata dengan kelompok tikus normal. Pemberian diet tepung buah utuh pisang Uter mampu memproduksi asam lemak rantai pendek lebih banyak dibandingkan diet tepung daging buah dan tepung kulit. Hal ini kemungkinan disebabkan kandungan pati resisten dalam pakan lebih banyak dan lebih mudah terfermentasi. Pati resisten yang masuk dalam sekum dan komposisi serta struktur fisik dari pati resisten berpengaruh pada produksi asam lemak rantai pendek. ${ }^{17}$ Pada penelitian ini tidak dilakukan pemerikasaan komposisi dan struktur fisik pati resisten yang terkandung dalam ketiga tepung, sehingga analisis hanya dapat dilakukan berdasarkan jumlah makanan yang dikonsumsi tikus.

Kandungan pati reisten pada diet tepung buah utuh terbukti meningkatkan kadar asam lemak rantai pendek. Pendapat lain menjelaskan bahwa asam lemak rantai pendek (meliputi asetat, propionat dan butirat) di dalam kolon mempunyai peran dalam berbagai hal. Asetat dipergunakan sebagai sumber energi utama di dalam kolon, propionat dapat menekan sintesis kolesterol, sedangkan butirat diduga berperan dalam menekan proliferasi sel kanker. ${ }^{7}$ Hasil penelitian ini sejalan dengan penelitian Rosida, kandungan pati resisten pada tepung pra-masak pisang tanduk dan pisang raja nangka dapat meningkatkan kadar asam lemak rantai pendek.

Berat total digesta berbeda antar kelompok. Hal ini mungkin disebabkan oleh adanya kandungan pati resisten dan serat pangan dalam tepung pisang yang tidak tercerna, dan keluar bersama digesta. Peningkatan berat digesta disebabkan oleh terikatnya air yang dibuktikan dengan pengukuran kadar air digesta sebagai berikut, kadar air digesta pada kelompok tikus HK-BU dan HK-DB lebih tinggi dibandingkan kelompok tikus STD dan HK-KN. Semakin banyak serat yang dikonsumsi, maka semakin besar kemampuan mengikat air dan senyawasenyawa organik. Semakin banyak serat yang dikonsumsi maka semakin besar kemampuan mengikat air sehingga feses lebih mengembang dan berukuran besar serta mudah dikeluarkan.

Fermentasi pati resisten di kolon dapat meningkatkan kekambaan (bulky) fekal dan menurunkan $\mathrm{pH}$ kolon. Penurunan $\mathrm{pH}$ karena produksi SCFA menyebabkan inaktivasi enzim $7 \alpha$-dehidroksilase sehingga konversi asam empedu primer menjadi asam empedu sekunder terhambat. ${ }^{18}$ Hasil penelitian ini berbeda dengan penelitian-penelitian yang lain bahwa konsumsi pati resisten dapat menurunkan $\mathrm{pH}$ digesta. Pada penelitian ini $\mathrm{pH}$ digesta kelompok tikus dengan diet tepung daging buah, buah utuh dan kelompok tikus normal sama, $\mathrm{pH}$ terendah pada kelompok tikus hiperkolesterol.

\section{KESIMPULAN}

Pisang Uter menunjukkan efek penurunan kolesterol total, trigliserida, dan LDL terutama pada tepung buah utuh dan tepung daging buah, sedangkan tepung kulit pisang tidak berefek. (revisi utk review 1 dan 2)

\section{UCAPAN TERIMA KASIH}

Penelitian ini dapat terlaksana dengan dukungan berbagai pihak. Peneliti mengucapkan terima kasih yang sebesar-besarnya kepada Badan PPSDM Kementerian Kesehatan RI atas dukungan pembiayaan penelitian. Kapala Balai Litbangkes Magelang dan semua pihak yang telah membantu terlaksananya penelitian ini. (sudah tercantum di draft artikel) untuk review 1 dan 2

\section{DAFTAR RUJUKAN}

1. Kementerian Kesehatan RI. Laporan Nasional Riskesdas 2018. Badan Penelitian dan Pengembangan Kesehatan. Jakarta. 2018.

2. Henry Jeya. Functional Food. European Journal of ClinicalNutrition.2010;64:657-59.

3. Nugraheni M, Hamidah S, Auliana R. Pengaruh konsumsi crackers kentang hitam (Coleus tuberosus) kaya Resistant Starch tipe 3 terhadap profil lipida tikus yang menderita hiperkolesterolemia. Jurnal Penelitian Saintek. 2016;21(1):21-31. 
4. Zaragoza EF, Riquelme-Navarrete MJ, Sanchez-Zapata E, Perez-Alvarez JA. Resistant starch as functional ingredient: A review. Food Research International. 2010; 43(4): 931-942. http://doi.org/fgpc2w.

5. Rachmandiar R. Perbedaan pengaruh jus kacang merah, yoghurt susu, dan yoghurt kacang merah terhadap kadar kolesterol total dan trigliserida serum pada tikus dislipidemia. Artikel Karya Tulis Ilmiah Mahasiswa Program Studi Kedokteran Umum. FK. Undip Semarang. 2012.

6. Hernawati, Manalu W, Suprayogi A, Astuti DA. Perbaikan parameter lipid darah mencit hiperkolesterolemia dengan suplemen pangan bekatul. MKB. 2013; (45)1: 1-9.

7. Rosida, Rosida DF. Evaluasi nilai gizi tepung pra-masak pisang tanduk dan pisang raja nangka. J Teknol dan Industri Pangan. 2011;22(2):125-29.

8. Musita N. Kajian kandungan dan karakteristik pati resisten dari berbagai varietas pisang. Jurnal Teknologi Industri dan Hasil Pertanian.2009;14(1): 68-79.

9. Kusumawardani HD. Profil lipid dan karakteristik digesta tikus Sprague-Dawley hiperkolesterol setelah pemberian diet tepung pisang uter (Musa paradisiaca Linn). Thesis Program Pascasarjana Universitas Gadjah Mada Tahun 2016.

10. Charan J, Kantharia ND. How to calculate sample size in animal studies. J Pharmacol Pharmacother. 2013; 4(4):303-06.

11. Reeves PG, Neilson FH, Fahey GC. AIN93 porified diets for laboratory rodents : final report of the american institute of nutrition ad hoc writing committee on the reformulation of the AIN-76 a rodent diet. J.Nutr. 1993;1223:1939-51.

12. Martati E, Lestari LA. Pengaruh pemberian khitosan terhadap profil lipid serum darah tikus Sprague-Dawley. Jurnal Teknologi Pertanian. 2008; 9(3):157-64.

13. Maryanto S, Fatimah S, Sugiri, Marsono Y. Efek pemberian buah jambu biji merah terhadap produksi SCFA dan kolesterol dalam caecum tikus hiperkolesterolemia. Agritech. 2013;33(3): 334-36.

14. Anonim. Official Methods of Analysis. AOAC International. USA. 2005.

15. Nurdin NM, Rimbawan, Marliyati SA. Akumulasi lipid hati dan profil lipid darah tikus Sprague Dawley yang diintervensi minyak super olein dan olein. J Gizi Pangan. 2016;11(1):67-74.

16. Hunter JE, Zhang J, Kris-Etherton PM. Cardiovascular disease risk of dietary stearic acid comapred with trans, other saturated, and unsaturated fatty acids: a systematic review. Am J Clin Nutr. 2010;91:46-63.

17. Zhou M, Pu C, Ia L, Yu S, Zhu B, Cheng R, Su L, Zhang J. Salecan diet increase short chain fatty acids and enriches beneficial microbiota in the mouse cecum. Carbohydrate Polymers. 2014;102: 772-79.

18. Kaczmarczyk MM, Miller MJ, Freund GG.The health benefits of dietary fiber : beyond the usual suspect of type 2 diabetes mellitus, cardiovascular disease and colon cancer. Metabolism Clinical and Eperimental. 2012; 61: 1058-66. 